\title{
Research and Discussion based on New Model of College English Teaching
}

\author{
Xuwei Li, Feipeng Li \\ Baoding University, Baoding, 071000, China
}

\begin{abstract}
Keywords: College English teaching, New education model, Cultivation of English talents, Teaching exploration
\end{abstract}

\begin{abstract}
With the deepening of reform and opening up of China, the international exchange has been increasingly close, and more and more foreign enterprises have come to China for development. The demand for the English talents is increasing, and accelerating the cultivation of English talents with high professional level and continuously exploring the teaching model are the key to improve the English teaching in universities. In this paper, the new model of college students' English teaching is analyzed, and by listing the specific English teaching model, its significance in the university English teaching is analyzed in the hope of providing some referenc es for relevant education departments.
\end{abstract}

\section{Introduction}

With the continuous improving and adjustment of market economy, the demand of English talents in economic development is continuously increasing, which proposes higher requirements for the college English teaching. Under the traditional English teaching model, universities can deeply interpret the textbook knowledge, so that the students can study along the designed knowledge context. However, such traditional teaching model is still dominated by the teachers' teaching, and can highlight the students' leading status in English teaching. Furthermore, the class teaching model is not so novel, and facing the boring English knowledge, the students cannot mobilize their incentives. Therefore, aimed at the problems above, it is very important to research the new English teaching model of college students, and this plays an active role in improving the students' English cognition, enriching class contents and improving the students' incentives.

\section{Model and characteristics of new college English teaching}

With the increasing of demand for English talents, the application of English teaching model in universities is significant to improve the English teaching and promote the development of English teaching. In the new times, many new English teaching models have been well applied in the college English teaching, which have promoted the teaching reform progress and reflected their uniqueness in English teaching. The following is the specific analysis on the new English teaching models and their respective characteristics.

\section{Scaffolding teaching model}

The scaffolding English teaching model appeared in foreign countries first, and has been widely used in recent decades, and its specific definition is to provide a knowledge structure frame for the English learners, deepen the students' understanding to knowledge, and under such frame constructed, the students can deeply understand the specific problems and can apply such "scaffolding" to guide the students for study better.

The scaffolding class teaching model can combine "teaching" and "learning” very well, can deal with the relation between the two very well and can be taken as an important carrier for the students' independent learning and group learning. Besides, with its individualized characteristics, the scaffolding class teaching is appropriate for students of different learning levels, and the students can concentrate their shortcomings whether in English listening, speaking, reading and writing or the practical English application on the teaching and highlight their individualized development. 
However, with the successive merging of other teaching models, it is required to maintain the principle of appropriateness and properness in the application of such scaffolding teaching model.

\section{Multimedia computer-assisted college teaching model}

The multimedia computer-assisted college teaching model is a very important teaching model, an auxiliary English teaching technology and the most important teaching assistance equipment in the current English teaching. As an emerging teaching means, multimedia computer-assisted foreign language teaching is emerging with the development of information technology and is widely applied in the modern English teaching. First, the multimedia computer-assisted foreign language teaching can meet the demand of English teaching environment in universities very well, and the teaching theory and information technology formed on this basis constitute the structure of multimedia teaching system, and can generate a certain scene effects and interaction effect when applied in the multimedia English teaching model, so that the students can deepen the knowledge understanding more intuitively and comprehensively. However, the multimedia computer-assisted foreign language teaching is just a teaching assistance means, if used to much or applied to carry out other activities, it will influence the normal teaching, disturb the normal teaching order and the class arbitrariness will be increased, which is unbeneficial to carry out the normal teaching activity.

\section{Arbitral college English teaching model}

Arbitral college English teaching model is not difficult to be understood, which means that the process in which the teachers set English learning objective in advance and guide the students to achieve the learning objective by various means. The students can complete the study task by independent learning or group discussion. Under such teaching model, the students will inevitably acquire knowledge through various learning channels, thus cultivating their active learning ability.

As early as in the 1980s, relevant foreign scholars proposed the task-oriented learning model, for example Brown et.al, Duff, Candin, Foster and Skehan et al. deeply and systematically discussed and researched the task-oriented learning model. The characteristic of such teaching model is to be able to fully use the language advantages in the process of learning, for example, the language systematicness, logics and regulation, and it can express language in a more truthful, natural and smoother way at the same time, so it can be said to be a teaching model with very strong interaction. The students can repeatedly practice the language learnt in the ordinary study and the communication between students and teachers, students and students can be very smooth, so that the students can build the objective awareness. It can be said that the task-oriented English teaching model is relatively open, and is encouraging, and it is very suitable for the independent research and discussion of college students in the ordinary study.

\section{Random access college English teaching model}

The random access college English teaching model is one of the access teaching models, and its basis is cognitive flexibility. The random access teaching model can make the students analyze and explore problems form different aspects, and they can learn the same content in the same learning scene, so that the learning contents can be displayed more completely. For example:

I saw Paul yesterday;

I went to borrow a saw from him;

I went to saw the table-led off;

In the sentence above, the word most frequently is "saw", and it has different meanings. The students can understand the meaning of this word, and have deep understanding "saw", and after summarizing its meaning, the students can summary "I saw a saw saw a saw", and using this arbitral English teaching model is very suitable to improve the English reading skills and writing skills. 


\section{Problems existing in college English teaching model}

\section{The students are lack of independent learning ability}

Generally, the objective of college English education is to make the students obtain the method of independent learning and can master the English learning method, so as to build the objective of lifetime learning. At the same time, this is also one of the main objectives of the current teaching reform. Through the independent learning, students can build the learning objective consciously and select appropriate learning methods, so as to achieve the self-learning of the whole learning process. Overall, under the independent learning model, the students can enhance the sense of responsibility in learning and improve the learning efficiency. However, the traditional passive English learning model is dominated by the teachers' teaching, the teachers generally make the course plan, and interpret the knowledge according to the context of the textbooks, the students only need to listen, memorize and practice, and repeat these learning steps. In the long term, the students are easy to forget much knowledge they memorize. In addition, with the overall arrangement of students, the students will rely on teachers, which is not beneficial for the cultivation of independent learning.

\section{The students have poor self-discipline under the traditional teaching model}

From the current college English teaching effect in China, quite a number of students are disqualified in English, and their actual English application is very limited, even many of the English major students cannot fully use their knowledge to carry out work, causing the loss of education value. The main reason for the problems above is that the students cannot restrict their behaviors effectively, and under the traditional teaching model, the students should study according to the contents stipulated in the teaching plan, and can graduate smoothly only after being qualified in examination, and this increases the students' burden intangibly, causing that they lose interest in English learning. Many students cannot listen efficiently in class and study carefully, and often have the problems of distraction and inattention, and after class, they cannot restrict themselves, because of loose learning atmosphere in universities, once in case of any temptation, the students will lose interest in English learning. Therefore, influenced by the traditional English teaching model, learning environment in universities and their students' willpower, it is becoming very intractable to improve the students' professional English ability.

\section{Under the traditional teaching model, the teaching task is heavy, teachers' quality and quantity are limited}

With the continuous expansion of recruitment in universities, the number of students learning English in universities is continuously increasing, while with the increasing of number of students, the teachers in universities must be increased. However, many universities cannot do this work very well, and there are usually the problems of great mobility of teachers, poor teaching ability and limited comprehensive English ability, which seriously influences the normal English teaching. In addition, under the traditional English teaching model, many universities adopt credit system, and the English courses are decreasing in setting, and the teachers should teach strictly according to the course outline. This means that under the limited class hours, the teachers have many contents to teach and the teaching task is very heavy. In many times, in order to complete the teaching task, the teachers will attend to trifles and neglect the essentials and do not concern the cultivation of students' abilities, thus the teaching becomes stiff and inflexible.

\section{Countermeasures}

\section{Build the double teaching model of "teacher dominance-student subject"}

It can be known from the above demonstration that the traditional English teaching model has exposed many shortcomings, which seriously hinders the cultivation of English talents. Therefore, constructing a teaching model of "teacher dominance-student subject" can combine the teachers' values with the students' role, teachers become the knowledge guide and class teaching participants, and their main work in teaching is to design the teaching contents, solve the students' doubt, concern 
the students' interest and use flexible and diversified teaching means to carry out teaching. Under this teaching model, the teachers can create real teaching scene for the students, respect the students' interest and hobbies, so as to concern their individualized development by independently thinking over problems. In addition, the teachers should correctly understand their own role, convert the knowledge infusion into knowledge impartation, and set the class in combination with the class. Therefore, many college students love some front-edge things and have strong reliance and sensitivity to computer network. To this end, the teachers can demonstrate various pictures and texts by virtue of multimedia teaching means, and also can play the video contents to draw the students' attention and improve class efficiency. Overall, applying new English teaching model can replace the shortcomings of the traditional English teaching model, so as to improve the English teaching efficiency and improve the students' independent learning ability.

\section{Continuously improve the teacher cultivation system and improve their comprehensive quality}

Influenced by the traditional teaching model, many university teachers teach while learning, and there are many teachers without experience, which is unbeneficial to stably and continuously carry out English teaching. To this end, universities should train the teachers regularly in terms of professional knowledge and human quality and improve their English comprehensive ability. In addition, it is required to strengthen the cultivation of university English teachers' scientific research abilities, so that they can have innovation ability and can construct a systematic and comprehensive new English teaching model, and can fully understand and apply many new English teaching models currently, and create more teaching values within the limited teaching time. Teachers should continuously broaden their knowledge horizon, and involve in different fields and subjects, only in this way will it be able to achieve the diversified teaching, adapt to the actual demands of students and correspond to the teaching reform direction.

\section{Conclusion}

This paper mainly analyzes several new teaching models of college students' English teaching and demonstrates the shortcomings of the current college English teaching under the traditional teaching model. Finally, two suggestions are proposed aimed at these problems. So, to improve the college English teaching and accelerate the cultivation of English talents, it is required to continuously transform the English teaching model and play the value of new English teaching model.

\section{References}

[1] Lei Honglei, Exploration on College English Teaching Model under Remote Open Education Condition-One of the Research Reports on English Teaching of Undergraduate Class of Open Education Accounting, Journal of Hainan Radio and Television University, 2011,2(2):10-13.

[2] Li Xiangyi, Role of Teachers under Independent Learning Model based on Computer and Network Environment-Case Research on College English Teaching of Beijing Jiaotong University, Beijing Jiaotong University, 2019

[3] Guo Ying, Dominance by Learning, Diversified Interaction-Research on College English Teaching Model under Information Technology Environment, Journal of Heilongjiang College of Education, 2013,32(7):165-167.

[4] Du Zhoujun, Exploration on Innovative Model of English Practical Teaching in Higher Vocational Colleges-Take the Teaching Practice of Mianyang Vocational Technical College, Popular Literature, 2012(4):264.

[5] Lei Xia, Research on English Teaching Innovation of Higher Vocational Colleges based on Network Space-take "Vocational Education Express" Network Space Teaching of Hunan Vocational College of Technology as an Example, Overseas English (first), 2015(2). 